\title{
Herbie Wolf, Poet
}

\section{John F. Gilgun}

Herbie Wolf felt good, and why in hell shouldn't he? On Tuesday he'd gotten the letter from Sundial Press saying they were going to publish his first book of poems, Spring Training; and then, on Friday, Dean Parrish had told him that, because of the book, they were going to make him an assistant professor with the understanding that, if he stayed on for another three years, he'd be given tenure. Of course, being made assistant professor meant a twelve hundred dollar raise; and Sundial Press was sending him seven hundred; and, who could tell, he might have the kind of success Rod McKuen had had (Spring Training would have wide appeal for a book of poems) and make millions. So he and Jeanie spent Saturday afternoon looking at houses in the Wildwood Heights Subdivision and in Melrose Park. They came home about six o'clock and Jeanie was a little nervous, because they had asked a lot of people over for what Herbie called a Victory Party at eight and that gave her only two hours to get supper ready, put Dougie to bed, clean up, get dressed and so forth.

"So don't worry," Herbie said, opening a bottle of Scotch. "These people, they're our friends. What do they care if the house is a little dirty? They want to get drunk a little and celebrate my success. What do they care?"

"I care," Jeanie said, going into the kitchen. "That's who cares."

Herbie Wolf stood at the window looking out at the street. A crumby street; a crumby half of a duplex apartment; a lousy instructorship at Columbine College. But that was all over now; he'd made it, up on the first rung, maybe even the second; he was being published; he was an assistant professor. And he wouldn't stay there long either. There would be other books and better jobs; some day maybe even Yale or Columbia. From Columbine to Columbia: he could call his autobiography that. People wrote autobiographies now about how they'd made it; look at Podhoretz. Some day, like Podhoretz, he too, Herbie Wolf, would be invited to Sutton Place. Herbie Wolf, Poet. He swallowed some Scotch, turned and went into the kitchen. Dougie was fussing in his highchair and Jeanie was messing 
around with some Gerber's baby food. Herbie grabbed her around the waist and buried his face in her soft, moist neck, saying, "I made it, baby; son of a bitch, I made it; I made it, Jeanie, I did it; oh son of a bitchin' mother-fuck I made it!"

People started arriving about eight-thirty. They had invited about thirty people, so by nine o'clock the room was packed. Herbie and Jeanie went around, collecting hats and coats, meeting people at the door, playing a game they called Young Suburban Married. ("What would you like to drink, Dr. Wilson? Scotch, bourbon, vodka? A martini?") It had started to snow outside. "Hey," Herbie shouted, over the heads of his guests. "It's like Joyce's The Dead, only it isn't Christmas!"

"It is for you, baby," Sheila Green said, throwing her arms around his neck. Sheila was the only other Jew in the English department; she was married to Mortie Green in Business Administration and she taught a few courses in Comp. Lit. "It's like a second Bar Mitzvah for you, Herbie, huh?"

Herbie kissed her on the mouth. He could smell bath oil and perfume and a little bit of the booze she'd had before coming over. At forty-five, she was still in there, Herbie thought; still in there pitching, vital and alive. "You're a sweet piece, Sheila," he said, slapping her on the ass. "You're my Yiddische Muse."

Mortie Green was beaming over Sheila's shoulder, his little salt and pepper toothbrush-moustache twitching. "I knew you'd make it, Herbie," he said, reaching over and giving him a thunderous pat on his right shoulder. "You got the stuff, boy; you got success in your blood. I knew it from the first time I saw you."

Then Will Wemberley, Herbie's Department Chairman, was there, in his tattersall vest and hopsack suit. Wemberley was only five years older than Herbie. He had worked his way up from nothing to Department Chairman and he had done it with guts and determination and a lot of chutzpah. Wemberley and Herbie understood each other. "Well, man, congratulations," Wemberley said, shaking his hand. (Herbie noticed a briar pipe in the pocket of Wemberley's jacket. Herbie knew that Wemberley had not smoked a pipe until he became Department Chairman. Smoking a pipe, that went with the territory.) "We'll be seeing you around here for a couple of years yet, I guess."

"I guess," Herbie said, with an ironic smile.

Herbie took Dean Parrish's coat. "Good evening, Dean Parrish," he said. "Snowing pretty hard now, isn't it?"

"Not so bad," Dean Parrish said. "A little slippery."

Dean Parrish, the Ultimate Goy: white hair and a white moustache. A combination of Dean Acheson and Louis Calhern in The Asphalt Jungle. A Chesterfield coat and a white silk scarf: yes, even that. "I'm glad you could come, Dean Parrish," Herbie said. Over Parrish's shoulder Herbie could see that Jeanie was taking Mrs. Parrish's coat in another part of the room.

"I guess we can consider you a real member of the faculty now," Dean Parrish said. The light from the porch outside struck Parrish's white head and sent out spokes of radiance. Herbie's hand trembled as he took Parrish's scarf. 
At nine thirty Herbie went into the kitchen and drew Jeanie aside. them?"

"Marina and Bill aren't here yet," he said. "Do you think I should phone

Jeanie seemed about to say something, but she reconsidered. Instead she gave him a funny look.

"But they're not here," Herbie said again.

"They're probably on their way. But phone if you want to."

"Oh, well," Herbie said. "Why phone? You're right. They're probably on their way."

But at ten o'clock they still hadn't arrived. They were the only friends he'd invited who hadn't come. Herbie knew where they were too; they were having dinner at Tom Cord's place. Tom Cord was the only person in the English Department Herbie hadn't invited to the party. ("Why invite my competition?" he'd said to Jeanie earlier.) Cord wasn't competition any more, but he had been three years earlier, when Herbie arrived at Columbine; and a guy who's been competition once remains competition, even after you've beaten him. That's the rule in street fighting; even if the guy is down, don't offer to shake his hand; he might get up again, you never could tell. Herbie had played football in high school back in Philadelphia and sometimes he thought he hadn't forgotten a single opponent he'd faced in those four years. He'd take them on all over again if they showed up anywhere in his vicinity. Short, squat and stocky (a girl had called him a "gigantic toad" once and he still had occasional fantasies in which he punished her for that), he'd played right tackle, though at 165 pounds he was too light for that position. He liked to think he made up for the deficiency in weight with tenacity, guts, determination and the sheer power to hate.

But by ten thirty Marina and Bill still hadn't arrived and Herbie decided that he couldn't be happy until they got there.

Back in 1965, when Herbie first came to Columbine, he could see what the situation was right away. Tom Cord had been hired three years earlier as a kind of resident writer because, at that time, Tom's novel, Tea at Four O’Clock, had been accepted for publication by a major house in New York. But something went wrong with the negotiations; Tom had some trouble with his editor; there was one of those major shake-ups on the editorial staff; and the contract was broken. Since then Tom had been unable to write; he had developed a block. Nor was he able to place the novel with another publisher. For the first few months Herbie had been forced to share an office with Tom Cord, space was so limited at Columbine; yet it didn't take Herbie long to discover that it wasn't really a space problem. Wemberley had put them together to see what would develop. ("Is that Wemberley a sadist or is he a sadist?" Herbie had said to Jeanie.) Herbie waited for the right moment and then asked Wemberley to give him another office. "I don't want to share an office with a loser," Herbie had said. So Wemberley had moved him out of the annex and into an office in the main building. Cord of course had stayed where he was. ("Wemberley is a sadist!" Herbie had decided. "Son of a bitchin' Wemberley!") Meanwhile Cord kept trying to write. There was no time to work on a novel, so he tried short stories. But 
he couldn't finish a single one. He tried poetry, but he couldn't write a decent line. Herbie had stopped by Cord's office early one morning, just to bug him a little. "Tom, you're like a constipated cat," he'd said. "Always straining and straining. Why don't you just sit down and write? It's easy. Hell, I can knock off a poem in twenty minutes; sometimes I write one in the morning when I'm taking a crap."

"I just write prose," Cord had answered. "I'll never be a poet."

"Me, I figured out a long time ago there's no percentage in writing prose It takes too long and the rewards aren't that great. And it's hard to get that kind of stuff published. Poems you can publish anywhere. They're cheap to print and they don't even have to make sense. How long did it take you to write that novel, two years? And what did you get for it? Chickenshit, right?"

Right. But Cord hadn't replied. One thing that disgusted Herbie about Cord was that Cord wouldn't fight back. Not fighting back, that was the mark of a loser. Herbie recognized a loser the first time he saw Cord; and Herbie had been right. The proof? Cord's contract had not been renewed this year.

Funny the way things worked out. On Friday, as Herbie was phoning Jeanie to tell her he'd been made assistant professor (using the phone in the main office of the English House), Cord had come in to get his mail. Herbie had watched him as he opened the letter, the letter telling him that he was through, and seen him turn pale. That was all Herbie needed to know. Cord was finished. But it had to be that way, didn't it? And Herbie had known it from the beginning. People like Cord always lost out; that just happened to be the way it was.

But at eleven o'clock Marina and Bill still hadn't arrived and Herbie had gotten morose. He was beginning to come down; the alcohol was beginning to depress him; and he could feel the edge of a mean temper moving in. fault.

"They're still not here," he said to Jeanie, as though it was somehow her

"Look," she answered. "They're grown-up people. You can't boss them around. Now they'll be here; just give them time."

"If they're not here in twenty minutes I'm going to call Cord's place."

Jeanie shrugged. "Have it your own way," she said, moving off into the crowd with a bowl of cheese-dip.

At eleven-twenty they still hadn't arrived. Herbie decided to give them five minutes more. He finished a can of beer. (He was trying to keep his temper under control with cold beer, trying to come down slowly, smoothly, gently; trying to hone down the raw, broken edge of his mood.) But at eleven thirty they hadn't come, so he called Tom Cord.

"Hello," Cord said, in what seemed to Herbie a sleepy voice. (Was I wrong? Herbie asked himself.)

"Hello, Tom," Herbie said. "Say, Tom, this is Herbie Wolf. Are Marina and Bill Jennings over there? I'd like to talk to them."

"No, they're not, Herbie," Cord answered. "But I'm glad you called. I wanted to congratulate you on your book. It's a great feeling when you get your first book accepted and you must feel great. It's a real great thing for you. 
Real great."

He sounded like he really meant it. Maybe he did! How could a guy tell? How could a guy ever figure out somebody like Tom Cord? But maybe Cord was just a super-cool character, Herbie thought. But being cool, what good did that do you, when you were a loser too?

Herbie felt a sharp coldness rising up around his ankles. Someone had opened the front door. He looked up. Over the heads of his guests he could see Jeanie talking to two people who had just come in. Who were they? Marina and Bill Jennings.

"Goodbye, Cord," Herbie said. And he hung up the phone.

At one o'clock in the morning, Mortie Green, completely crocked by then, dragged a chair in from the kitchen, climbed up on it and shouted in a cornball Yiddish accent, "I want you should hear from a boy what made good! I should know from success, me, Mortie Green, a schlepper like me? But here is a boy what can speak on that subject with absolute authority, believe you me-Herbie Wolf!"

Half the guests had gone home; Parrish was gone; Wemberley was gone. The ones who remained were so smashed they could hardly stand; they were all just kind of leaning against each other for support; a stiff breeze would knock them all over. Mortie Green stepped down and motioned Herbie toward the chair. Herbie climbed up and looked down at his friends. They were applauding. $\mathrm{He}$ drank some beer while they quieted down and then said, "I want you should know my old man was a butcher. He cut meat in a store. As a butcher, believe me, he worked his fingers to the bone." He wasn't as good at this kind of thing as Mortie; better drop it. "My mother helped organize people for the International Ladies Garment Worker's Union during the Depression. My parents worked their asses off to put me through Temple University. I had to live at home and commute to school. I only wish that my mother and father could be here now to see that all their sacrifices were not in vain." All of a sudden Herbie wondered what he was doing up there; it had started as a put-on and it was still a put-on. Looking down, he thought he could see that all the people under twenty-five could see that it was a put-on (the kind of thing London Lee might do); he thought he could tell that by looking in their eyes. But the older people, like Mortie and Sheila Green, seemed to be taking it straight. Or did they? Herbie couldn't tell. Hell, his father hadn't worked as a butcher since 1937, when he took a job as sales manager for Lipsky's Wholesale Fur House and began to work his way up, so that by the time Herbie got out of high school his father was earning $\$ 18,000$ a year and could afford to give Herbie his own car. It was in that car, a five year old Ford Galaxie, that Herbie had commuted back and forth to that rich boy's school. And he lived at home because it was more comfortable than a dorm; and besides, as an only child, he figured he owed it to his parents. As for the ILGWU, his mother had worked as a union organizer for about three weeks in the late '30's and then quit because she decided it was all a lot of crap.

But Herbie had started now and he couldn't stop. "I saw a need in poetry," he said. "To make a plain prose statement in poetry. To write about things that 
all of us know about, like the movies we saw as kids and the radio shows we listened to. I saw there was no one in America who could describe a lower-middle class street in Philadelphia or a stickball game or a manhole cover or kick-the-can. Enough of this Wallace Stevens crap. Who needs it?" What am I doing? he asked himself. I don't mean a word of this. I'm not even being fair to my own stuff! "Hand me up a drink somebody. Whitman Wolf needs a shot. America, right, that's it! Where but in America could the son of Jewish immigrant parents," (both his mother and father were second generation), "work his way through a rich boy's school and publish a book of poems before he was thirty-five? As my old man sailed into New York Harbor on that fateful day in 1926 and saw the Statue of Liberty through the mist, he knew that his son would be a famous poet some day. He turned to the woman who would later become his wife and my mothershe was working her passage across as a waitress-and said, "Some day, some day, Myra, all dis will be Hoibie's!' "

Everyone was laughing; everyone had known it was a put-on. Herbie began to laugh himself. A put-on, sure. Probably he'd been the only one there who hadn't been sure. Mortie handed him a glass of Scotch, just Scotch, no ice or water. He drank it down.

"Just one last thing. I've been feeding you a line and you all know it. But let me tell you one thing seriously. When I was a kid they used to call me a great competitor;' it was a phrase they used. It meant you weren't a sissy; you could take it, you were tough, you had guts; you were really in there, fighting hard. Grownups used it in connection with kids. I don't think kids used it with other kids. I guess we had some other words we used. Anyhow, I knew when I was a kid, and I know now, there's only one way to get anywhere in this world and that's to compete. Look, I have no front teeth. Believe me when I tell you this is a partial plate. Why? Because I got my front teeth kicked out in a football game in 1955. We were playing East Camden for the title, and we won. Listen, there's no other way to do it. I've got scars on my body and I'll be buried with those scars, but it's worth it if you win. You have got to compete. My old man told me that when I was a kid; and I'll tell my kid Dougie that too, when he gets old enough to understand."

His kid, Dougie! He already had doubts about Dougie. The kid cried too much and was scared of his own shadow. What kind of kid was that for a famous poet-father to have? Dougie! Herbie had put part of one of Jeanie's tranquilizers in his strained spinach so that he'd sleep through the party and he was knocked out now, stoned, in the back bedroom. The youngest junkie on the block, Herbie had called him.

"You're a great man, Herbie," Mortie Green said, reaching up to help him down from the chair. "Even if you are full of crap."

Had Mortie said that? No. Yes. No. Herbie had said it himself. "Mort you're full of crap." But he'd said it in a funny, joking kind of way. So Mortie was laughing now and hugging him around the shoulders; and his little moustache was bristling over his bright yellow teeth. 
Herbie was standing on an empty football field alone; he was the coach, he was the team, he was the whole damned school. He felt good, but he had a tense feeling in his gut because he knew that he would have to do it all alone. No one else had the knack; no one else had the skill; no one else knew the secret. He looked over at the dark passageway under the stands. They were in there, he knew they were in there; why didn't they come out? He thought he could hear them breathing in there, but still they didn't come out. He felt angry; here he'd gotten himself into condition and all ready to go and they wouldn't come out.

Herbie was hurrying down Third Avenue in the early '50's, before they took the Elevated down; trains were rumbling over his head. He was hurrying to meet a girl and he was late. The street changed; he was on Orchard Street surrounded by peddlers, butchers, seamstresses, hungry kids, dogs and garbage. A woman was with him. She saw something in a shop window, turned to him and said, "It represents that worldly society at large where cold scepticism smothers our spiritual aspirations and makes the rest ridiculous."

"I'm afraid," Herbie answered.

He was hungry, but all the restaurants were closed. He had a dinner invitation, but it was for the week after next. He wanted to hurt the person who'd sent it but he couldn't remember who'd sent it. Oh. It was Cord. Well, fuck Cord! Herbie would rather go hungry.

Herbie was looking down into some oily water; it was the East River. His own face was looking back at him. His reflection was black. The black reflection opened its mouth. It had no front teeth. Through the mouth, the way led down into darkness, and Herbie was descending. I'm dreaming, he thought; I can wake up any time.

But he kept on dreaming; and the black jaws closed and began to move slowly from left to right, smashing Herbie to blood and flesh and water.

Herbie sat up, covered with sweat. He'd fallen asleep on the living room couch. The room was a mess around him, bottles, glasses, cheese-dip. Silence. Where was Jeanie? Damn it, it was morning; he could see a white light under the drapes. It was morning and he was hungry, wildly, ravenously hungry. He was so hungry, he hurt all over.

He went to the kitchen and made himself a roast beef sandwich, slicing off the rare pieces and ignoring the well-done; that was the way he liked it. Then he went to the bedroom and kicked the foot of the bed once or twice, to wake up Jeanie.

When she woke up, she said, "Isn't it awfully early?" from the pillow.

Standing there, looking at his wife, tearing at the roast beef, mustard and crumbs and drops of blood falling on his bare chest, Herbie said, his mouth full, "Take off those pajamas, Jeanie. I feel like fucking." 